\title{
SOCIO ECONOMIC CONDITIONS OF THE THARU COMMUNITY IN PATIHANI VDC, CHITWAN
}

\author{
Prem Raj Khaniya*
}

\begin{abstract}
The paper deals with the socio- economic conditions of the Tharu community in the Patihani VDC in Chitwan district. The paper is based on primary data for which a field survey was conducted in 2009. Questionnaire has been used as the major instrument for data collection. The total number of households covered in this study was 45. The heads of households were the respondents of this study. The study indicates that socio- economic conditions of the Tharus is gradually deteriorating.
\end{abstract}

\section{INTRODUCTION}

The Tharu Community is one of the major ethnic groups in the Tarai and it represents 13 percent of the total population in the region (CBS 2003). The largest Tharu population in Nepal is shared by Kailali district which is 206933 district 49.52 percent in the district total (Gyawali 1997). The Tharu population in Chitwan district is 4539212.80 percent in the total. In terms of percentage, Chitwan is the twelfth district.

The Tarai communities constitute 7.9 percent of Nepal's total population of which the Tharu forms one of the largest groups. The Tharu is the single largest ethnic group that represents 13 percent of the total population in the Tarai and inner Tarai districts. Cultural changes among the Tharus have been brought about by their contact with the neighbouring people of so called high cultures. They are gradually homing modification in their existing life styles. The main objective of this paper is to analyse the socio-economic conditions of the Tharu community in Patihani VDC, Ward No. 4 Kummiya in Chitwan district.

\section{METHODS AND MATERIALS}

The paper is based on primary sources of information obtained from field survey in 2009. The heads of the households were the main respondents whereas a number of interviews were taken with social workers and the senior citizens of the Tharus. Besides them, other documentary sources were also used. The analysis and interpretation is based on descriptive and qualitative approach.

\footnotetext{
*Associate Professor, Mahendra Ratna Campus, Tribhuvan University, Kathmandu, Nepal
} 


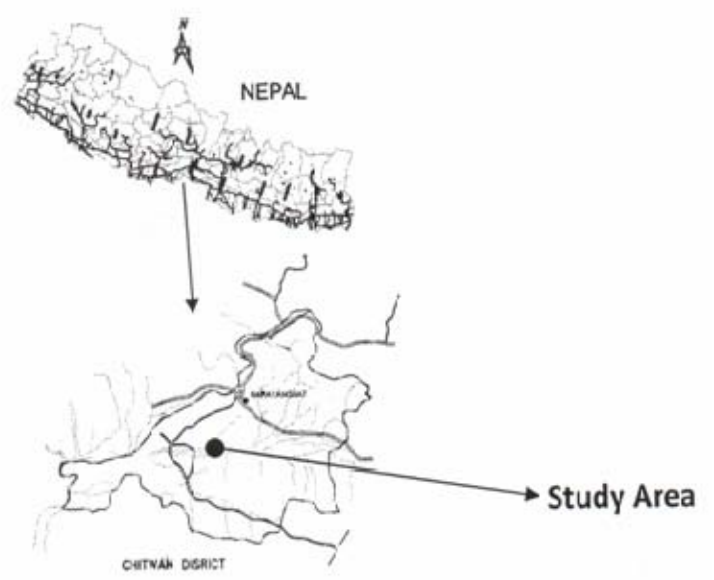

Fig

\section{SOCIO-ECONOMIC CONDITIONS OF THE THARUS}

The age and sex composition of population in any specific area has a deciding role on the future population growth, as for instance, if the proportion of women of the age between 15 and 49 is large, the birth rate of that area can be expected high. So the government should implement different programs more efficiently to reduce the birth rate. The data on age-sex composition of population are presented in table- 1 .

Table 1. Age-Sex Composition of the Tharus

\begin{tabular}{|c|c|c|c|c|c|c|c|}
\hline Age group & Male & $\mathbf{\%}$ & Female & $\mathbf{\%}$ & Total & $\mathbf{\%}$ & Sex ration \\
\hline $0-4$ & 4 & 2.9 & 3 & 2.2 & 7 & 2.6 & 133.3 \\
\hline $5-9$ & 10 & 7.4 & 9 & 6.5 & 19 & 69 & 111.1 \\
\hline $10-14$ & 15 & 11.1 & 12 & 8.6 & 27 & 9.9 & 125 \\
\hline $15-19$ & 12 & 8.9 & 10 & 7.2 & 22 & 8 & 120 \\
\hline $20-24$ & 12 & 8.9 & 15 & 10.8 & 27 & 9.9 & 80 \\
\hline $25-29$ & 15 & 11.1 & 20 & 14.4 & 35 & 8 & 75 \\
\hline $30-34$ & 17 & 12.6 & 12 & 8.6 & 29 & 12.8 & 141.6 \\
\hline $35-39$ & 16 & 119 & 12 & 8.6 & 28 & 10.6 & 133.3 \\
\hline $40-44$ & 8 & 5.9 & 17 & 12.2 & 25 & 10.2 & 47 \\
\hline $45-49$ & 9 & 6.7 & 9 & 6.5 & 18 & 9 & 100 \\
\hline $50-54$ & 8 & 5.9 & 10 & 7.2 & 18 & 6.6 & 80 \\
\hline $55-59$ & 6 & 4.4 & 6 & 4.3 & 12 & 4.4 & 100 \\
\hline 60 -above & 3 & 2.2 & 4 & 2.9 & 7 & 2.6 & 75 \\
\hline Total: & $\mathbf{1 3 5}$ & $\mathbf{1 0 0}$ & $\mathbf{1 3 9}$ & $\mathbf{1 0 0}$ & $\mathbf{2 7 4}$ & $\mathbf{1 0 0}$ & $\mathbf{9 7 . 1 2}$ \\
\hline
\end{tabular}

Source: Field Survey 2009.

The data in table 1 shows that 43.89 percent of the people is dependent. Generally the number of population has decreased with age. The highest proportion of population is in the age group of 25 and 29 and the lowest in age 0 4 and 60 and above respectively. 
The data show that the total population in the study area is 274 . The number of males and females are 135 and 139 representing 49.2 and 50.8 percent respectively. There is an excess of females over males. The overall sex ratio of the study population is 97.12 . It means there are 97 males for each 100 females.

\section{DEPENDENCY RATIO}

The dependency ratio in the given population is computed on the basis of its age structure. For this purpose, broad age groups should be identified. Population distribution by broad age group is presented in table 2.

Table-2. Dependency Ratio of the Tharus

\begin{tabular}{|c|c|c|c|c|c|}
\hline Age group & Male & Female & Total & \% & Sex ratio \\
\hline $0-14$ & 24 & 24 & 53 & 19.3 & 120 \\
\hline $15-59$ & 103 & 111 & 214 & 78.1 & 92.8 \\
\hline 60 -above & 3 & 4 & 7 & 2.6 & 75 \\
\hline Total & 135 & 139 & 274 & 100 & \\
\hline
\end{tabular}

Sources: Field Survey 2009.

It is obvious from data presented in table 2 that the population in young age group is 19.3 percent and the economically active age group represents 78.1 percent whereas the old age group represents only 2.6 percent. It gives the pictorial vision that generally decreasing percentage of population is succeeding.

Thus what we see is that the study area is in good situation because majority of population is independent and the highest proportion is represented by the active population.

The sex ratio of any population is affected by past fertility, mortality and migration. Like the age and sex composition, sex ratio has the deciding role in the development of every country. In the study area, most people generally think female to be as just means of reproducing children and mistress of the kitchen. They do not use the female for productive purposes. Other sex ratio by age group is presented in table- 3 .

Table-3. Sex Ratio of the Tharu and Nepal (2066)

\begin{tabular}{|c|c|c|}
\hline Age Group & Tharu* & Nepal(1988)* \\
\hline $0-4$ & 133.3 & 105.96 \\
\hline $5-9$ & 111.1 & 104.13 \\
\hline $10-14$ & 125 & 116.63 \\
\hline $15-19$ & 120 & $109 . .95$ \\
\hline $20-24$ & 80 & 91.13 \\
\hline $25-29$ & 75 & 96.45 \\
\hline $30-34$ & 141.6 & 92.31 \\
\hline $35-39$ & 133.3 & 106.96 \\
\hline $40-44$ & 47 & 100.27 \\
\hline $45-49$ & 100 & $113 . .84$ \\
\hline $50-54$ & 80 & 118.99 \\
\hline $55-59$ & 100 & 114.73 \\
\hline 60 -above & 75 & $109 . .76$ \\
\hline Total & $\mathbf{9 7 . 1 2}$ & \\
\hline
\end{tabular}

* Source: Field Survey, 2009. 
The data in table 1 shows that 43.89 percent of the people are dependent. Generally, the number of population has decreased with the ratio of age. The highest proportion of population is in age group 25-29 and the lowest in age 0-4 and 60 and above respectively.

The data show that the total population in the study area is 274 . The number of males and females are 135 and 139 representing 49.2 and 50.8 percent respectively. There is an excess of females over males. The overall sex ratio of the study population is 97.12. It means there are 97 males for each 100 females.

\section{DEPENDENCY RATION}

The dependency ration in a population is computed on the basis of its age structure. For this purpose, broad age groups should be identified. Population distribution by broad age group is presented in table 2 .

Table-4. Dependency Ratio of the Tharus

\begin{tabular}{|c|c|c|c|c|c|c|}
\hline $\begin{array}{c}\text { Age } \\
\text { group }\end{array}$ & Male & \% & Female & \% & Total & \% \\
\hline Below 14 & 24 & 21.5 & 24 & 17.3 & 53 & 19.3 \\
\hline $15-59$ & 103 & 76.3 & 111 & 79.8 & 214 & 78.1 \\
\hline 60-above & 3 & 2.2 & 4 & 2.9 & 7 & 26 \\
\hline Total & $\mathbf{1 3 5}$ & $\mathbf{1 0 0}$ & $\mathbf{1 3 9}$ & $\mathbf{1 0 0}$ & $\mathbf{2 7 4}$ & $\mathbf{1 0 0}$ \\
\hline
\end{tabular}

Source: Field Survey, 2009.

Dependency ratio is defined as the ratio of economically inactive population to economically active population which can be explained categorizing as youth dependency ratio and the ratio of the people under 14 years plus people 60 years and above, to the population aged 15 to 59. It is known as total dependency ratio. The higher dependency ratio is the sign of less development and low level of living standard and vice versa.

The data in table 4 present a picture of the economic implications of the demographic situation. The age of economically active people is considered from 15-59 years, but in the context of Nepal, active age is from 10-59 years. Thus the percentage of working population comes to about 78.1 percent and the rest 21.9 percent that includes children i.e. population below 14 years, which indicate the normal condition of the Tharu in terms of demographic character. And within the same sex, males and females are respectively 76.3 and 79.8 percent as economically active population. It means, in relative sense, females are in higher percentage of economically active than the males.

Table-5. Educational Status of the Tharus

\begin{tabular}{|l|l|l|l|l|l|l|l|}
\hline & Illiterate & Literate & $\begin{array}{c}\text { Under } \\
\text { S.L.C. }\end{array}$ & S.L.C. & I.A. & B.A. & M.A. \\
\hline Total & 99 & 76 & 65 & 18 & 12 & 4 & 0 \\
\hline Percentage & 36.1 & 27.7 & 23.7 & 6.6 & 4.4 & 1.5 & 0 \\
\hline
\end{tabular}

Source: Field Survey, 2009. 
Education is one of the important needs of life. A few degree of literacy is an obstacle to economic growth. Educationally, the Tharus are in a backward condition.

According to the Shaichhik Jhalak (DEO, Chitwan 2008), the total literacy of Chitwan was 71 percent and the percentage of literate people of Nepal has increased for some years. If we compare this percentage with the national, zone and district level literacy it is only tolerable. The educational condition of the Tharus is presented in table 5 .

The data show that the educational status of the Tharus is poor. Among them, the percent of illiterate population is 36.1. The literacy rate is only 27.7 percent. The people under S.L.C. level are 23.7 percent where as the percentages for S.L.C., I.A. and B.A. are 6.6, 4.4 and 1.5 respectively. There are no schools in this ward. The secondary schools and campuses are located at a distance of $2 \mathrm{~km}$. There is no difficulty for the study but there is no M.A. degree with Tharu boys. Most of the Tharu students drop out in the school period.

The above description gives us a very clear picture of the educational level of the Tharus. There is no prospective future for the educated Tharus in this ward. Now, however, the situation is just beginning to change. The Tharus have realized the importance of education and the benefits of educational enlightenment. At present, more and more Tharu parents are sending their children to school.

\section{OCCUPATION}

The males and the females of the Tharus are today involved in agricultural occupation. Agriculture still constitutes the main source of income.

\section{CONCLUSION}

Present paper is an attempt to deal with socio-economic conditions of the Tharus in Patihani VDC, Chitwan. Age-sex composition of population, dependency ratio, sex ratio, economically active population and educational status are the areas covered in this paper. Based on the findings of the study, it is obvious that the government and local level organizations have to implement effective educational programmes and generat employment opportunities in order to raise the socio- economic conditions of the Tharus in the study area.

\section{ACKNOWLEDGEMENTS}

The author would like to express his gratitude to Somala Tharu and Ram Lakhan Tharu for their cooperation in various stages of data collection for this paper. Similarly, entire Tharu community in the study area deserves thanks for their cooperation in completing the questionnaires. 


\section{WORKS CITED}

CBS. 1988. District Profile, Central Bureau of Statistics, Kathmandu.

CBS. 2003. Popualtion Monograph of Nepal. Volume 1, Central Bureau of Statistics, Kathmandu.

DEO, Chitwan. 2008. Shaikshik Jhalak. District Education office, Bharatpur.

Gyawali, Damodar. 1997. The Tharus of Gulariya Area, Bardiya in Nepal Tarai: A study on Population and Health Perspectives, Research Report, Submitted to University Grants Commission, Nepal. 